\title{
KEBIJAKAN FORMULASI JUDI ONLINE DALAM HUKUM INDONESIA
}

\author{
Dewi Bunga \\ Program Doktor Ilmu Hukum Universitas Gadjah Mada \\ bunga8287@gmail.com
}

\begin{abstract}
Various electronic devices equipped with internet networks have opened up opportunities for emerging crimes in cyberspace. Online gambling is a form of traditional crime transformation that turns into a crime operating in cyberspace. In the formulation of legal policies in various countries, not all countries declare online gambling as a criminal act. There are countries that legalize online gambling, there are countries that are in the gray area, and some are banning online gambling. In this study there are two issues discussed, namely the application of jurisdiction in the criminal acts of online gambling and criminal law policies against online gambling. The application of jurisdiction in criminal acts of online gambling must pay attention to the rules of international law, where a country cannot enforce its rule of law in another country. Provisions regarding online gambling jurisdiction are regulated in Article 2 of Act Number 11 of 2008 concerning Electronic Information and Transactions. International cooperation in law enforcement on online gambling can be carried out as long as there are international agreements between countries and both countries alike establish online gambling as a crime. Criminal law policy on online gambling in Indonesia formulates online gambling as a criminal act as stipulated in Article 27 paragraph (2) of Act Number 11 of 2008 concerning Information and Electronic Transactions.
\end{abstract}

Keywords: Policy, formulation, online gambling.

\section{Pendahuluan}

Perjudian merupakan masalah hukum yang seringkali dikategorikan sebagai penyakit masyarakat. Dikatakan sebagai penyakit masyarakat karena orang yang berjudi sulit untuk lepas dari kebiasaan ini. Judi merupakan pertaruhan dengan sengaja, yaitu mempertaruhkan satu nilai atau sesuatu yang dianggap bernilai dengan menyadari adanya resiko dan harapanharapan tertentu pada peristiwa-peristiwa, permainan pertandingan, perlombaan dan kejadian-kejadian yang tidak/belum pasti hasilnya. ${ }^{1}$ Judi menimbulkan efek ketagihan karena pemainnya selalu berharap akan mendapatkan keuntungan. Jika menang, maka pemain akan mencoba kembali keberuntungannya, namun jika kalah, maka pemain akan kembali berjudi dengan harapan bahwa pada permainan berikutnya ia akan menang. Akibatnya, pemain judi online berupaya mencari uang dengan cara apa pun untuk digunakan sebagai modal judi, termasuk dengan melakukan kejahatan, seperti pencurian, penipuan dan sebagainya. Merujuk pada perkembangan judi online, TechAddiction mengungkap fakta sebagai berikut:

TechAddiction has provided a number of interesting facts on internet casinos as well as selected online gambling statistics:

a. "Pathological Gambling" was officially recognized as a clinical disorder in 1980 when it was first included in the DSM-III.

$b$. Although most people are able to gamble responsibly, it is estimated that $3 \%$ of the population struggles with pathological gambling. 
c. The first online casino launched in August of 1996 (InterCasino, based in Antigua). Eighteen games were available at the time. There are now thousands of internet gambling websites and new online gambling businesses appear every day.

d. Most online gambling websites are not affiliated with land-based casinos. This is widely thought to be because traditional casinos did not want to get involved with a business model that would take away from traditional sources of revenue. This policy appears to be changing as traditional casinos are now developing their own online gambling websites.

e. There are no official product safety standards and regulations for online casinos. Players who choose to wager at online gambling websites essentially do so at their own risk.

f. Playing on "free" internet gambling websites is a common activity for teenagers and young adults.

g. Research suggests that young males are most likely to engage in online gambling.

$h$. The first internet Bingo site went online in 1998.

$i$. The first online poker site (PlanetPoker) also started in 1998.

$j$. The number of online poker websites dramatically increased in 2003 when the World Series of Poker became a popular television program.

$k$. Total revenues from online casinos are difficult to pinpoint but have been estimated at $\$ 12$ billion in 2005 and 15.2 billion in 2006. In 2010, revenues were 29.3 billion.

l. One in five online gamblers may be pathological gamblers

m. Approximately $4 \%$ of teenagers have a gambling problem. ${ }^{2}$

TechAddiction telah memberikan sejumlah fakta menarik di kasino internet serta statistik perjudian online:

a. Sebuah. "Perjudian Patologis" secara resmi diakui sebagai gangguan klinis pada tahun 1980 ketika pertama kali dimasukkan dalam DSMIII.

b. Meskipun sebagian besar orang dapat berjudi secara bertanggung jawab, diperkirakan bahwa
$3 \%$ dari populasi berjuang dengan judi patologis.

c. Kasino online pertama diluncurkan pada Agustus 1996 (InterCasino, berbasis di Antigua). Delapan belas pertandingan tersedia saat itu. Sekarang ada ribuan situs web perjudian internet dan bisnis perjudian online baru muncul setiap hari.

d. Sebagian besar situs web perjudian online tidak berafiliasi dengan kasino darat. Ini secara luas dianggap karena kasino tradisional tidak ingin terlibat dengan model bisnis yang akan mengambil dari sumber pendapatan tradisional. Kebijakan ini tampaknya berubah karena kasino tradisional sekarang mengembangkan situs web perjudian online mereka sendiri.

e. Tidak ada standar dan peraturan keamanan produk resmi untuk kasino online. Pemain yang memilih untuk bertaruh di situs perjudian online pada dasarnya melakukannya dengan risiko sendiri.

f. Bermain di situs web perjudian internet "gratis" adalah kegiatan umum bagi remaja dan dewasa muda.

g. Penelitian menunjukkan bahwa laki-laki muda kemungkinan besar terlibat dalam perjudian online.

h. Situs Bingo internet pertama kali online pada tahun 1998.

i. saya. Situs poker online pertama (PlanetPoker) juga dimulai pada tahun 1998.

j. Jumlah situs web poker online meningkat secara dramatis pada tahun 2003 ketika World Series of Poker menjadi program televisi yang populer.

k. Total pendapatan dari kasino online sulit ditentukan, tetapi diperkirakan mencapai \$ 12 miliar pada 2005 dan 15,2 miliar pada 2006. Pada 2010, pendapatan mencapai 29,3 miliar.

1. Satu dari lima penjudi daring mungkin penjudi patologis

m. Sekitar 4\% remaja memiliki masalah judi.

Adami Chazawi dan Ardi Ferdian mengungkapkan "Kemajuan teknologi digunakan oleh orang-orang atau kelompok untuk melakukan perbuatan melawan hukum, menyerang pribadi, masyarakat, dan negara."3Kemajuan teknologi informasi berimplikasi pada praktik perjudian. Perjudian yang dulunya dikemas dalam bentuk permainan yang mempertemukan para pemain 
secara langsung di arena judi, kini perjudian dilakukan di dunia maya. Menurut Onno W. Purbo, yang disebut sebagai judi online atau judi melalui internet (online gambling) biasanya terjadi karena peletakan taruhan pada kegiatan olah raga atau kasino melalui internet. Judi online yang sesungguhnya adalah seluruh proses baik itu taruhannya, permainannya maupun pengumpulan uangnya melalui internet. Para penjudi akan diharuskan untuk melakukan deposit dimuka sebelum dapatmelakukan judi online. Hal ini berarti harus melakukan transfer sejumlah uang kepada admin website judi sebagai deposit awal. Setelah petaruh mengirim uang maka akan mendapatkan sejumlah koin untuk permainan judi. Jika menang maka uang hasil taruhan akan dikirim lewat transfer bank dan jika kalah maka koin akan berkurang. ${ }^{4}$ Kasus perjudian online sudah mulai menjadi perhatian dari penegak hukum. Direktorat Tindak Pidana Ekonomi dan Khusus (Dit Tipid Eksus) mengungkap jaringan internasional pengelola situs judi online. Total transaksi yang sementara terhitung sejak dua tahun beroperasi mencapai Rp 450 miliar. ${ }^{5}$ Mekanisme kerja judi online dilakukan dengan mencari member atau pemain dengan cara menelepon target untuk diajak bergabung di situs iMobet.Setelah pemain registrasi diteruskan kepada tersangka yang berperan sebagai admin untuk didata dan dikirimkan kepada trainer yang menurut pengakuan tersangka, server berada di Manila, Filipina untuk diterima sebagai anggota dan akan diberikan IP address. Setelah mendapat IP addres, maka pemain bisa mendeposit dana untuk melakukan taruhan di situs tersebut. Jika menang, maka uangnya langsung ditransfer ke rekening pemain oleh trainer. Demikian juga gaji admin dan sales dikirim melalui transfer rekening. Dalam sehari para tersangka bisa mengumpulkan uang taruhan sebesar Rp 100 juta hingga Rp 150 juta, atau dalam sebulan bisa mencapai miliaran rupiah. ${ }^{6}$

Kasus-kasus perjudian online menunjukkan betapa besarnya dampak negative dari penggunaan internet, sementara dilihat dari statistic penggunaan internet, masyarakat di benua Asia menjadi konsumen terbesar dalam penggunaan internet. Data ini dapat dilihat dari hasil survey yang dilakukan oleh Internet World Stats ${ }^{7}$ pada bulan Maret 2019, yakni sebagai berikut:

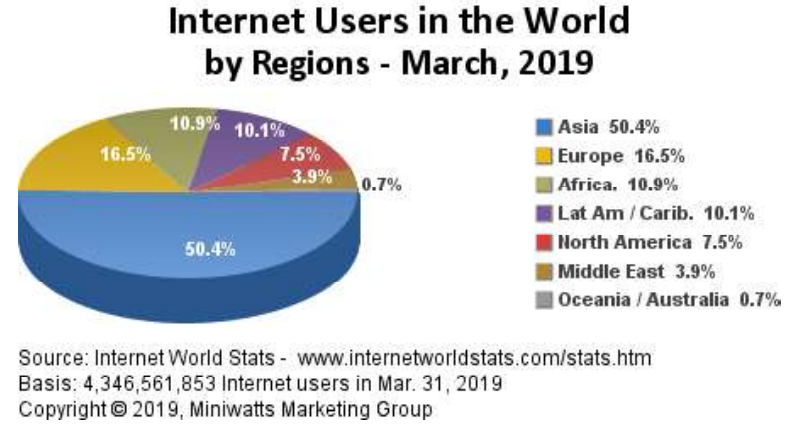

Dalam perundang-undangan di Indonesia, judi online merupakan tindak pidana sebagaimana yang diatur dalam Pasal 27 ayat (2) Undangundang Nomor 11 Tahun 2008 tentang Informasi dan Transaksi Elektronik yang menyatakan "Setiap Orang dengan sengaja dan tanpa hak mendistribusikan dan/atau mentransmisikan dan/ atau membuat dapat diaksesnya Informasi Elektronik dan/atau Dokumen Elektronik yang memiliki muatan perjudian.” Sebagai tindak pidana yang beroperasi di dunia maya maka tindakan ini dapat melibatkan yurisdiksi di beberapa negara yang berbeda-beda. Pelaku dan korban dapat berada di negara yang berbeda, begitu pula dengan IP addres yang digunakan. Dalam hal ini diperlukan suatu kajian mengenai penerapan yurisdiksi dalam tindak pidana perjudian online. Penelitian ini juga akan membahas mengenai kebijakan hukum pidana terhadap perjudian online.

\section{Penerapan Yurisdiksi dalam Tindak Pidana Perjudian Online}

Sistem hukum akan selalu berkaitan dengan sistem politik khususnya mengenai yurisdiksi, oleh karena itu meski secara analitis kedua hal tersebut dapat dipisahkan, hal ini berkaitan dengan diletakkannya peradilan sebagai posisi sentral di dalam tertib hukum, sedangkan perumusan kebijakan melalui badan legislatif sebagai inti kekuasaan politik. ${ }^{8}$ Penentuan yurisdiksi dalam suatu kejahatan transnasional (kejahatan yang melampaui batas negara) merupakan hal yang sangat penting untuk mengetahui hukum mana yang digunakan, dapat diterapkan dan dipaksakan terhadap suatu tindak pidana.

Pengaturan perjudian online sebagai perbuatan yang dilarang sebagaimana yang diatur dalam Pasal 27 ayat (2) Undang-undang Nomor 11 Tahun 2008 tentang Informasi dan Transaksi 
Elektronik menegaskan bahwa Indonesia mengkategorikan perjudian online sebagai salah satu kejahatan di dunia maya (cyber crime). Menurut Widodo, "cybercrime merupakan keseluruhan bentuk kejahatan yang ditujukan terhadap komputer, jaringan komputer dan para penggunanya, dan bentuk-bentuk kejahatan tradisional yang menggunakan atau dengan bantuan peralatan komputer."9 Perjudian online sendiri merupakan kejahatan tradisional yakni perjudian yang berkonversi menjadi kejahatan di dunia maya karena menggunakan peralatan elektronik dan jaringan internet. Cybercrime memiliki beberapa karakteristik, yaitu:

1. Perbuatan yang dilakukan secara illegal, tanpa hak atau tidak etis tersebut terjadi dalam ruang/ wilayah siber/cyber (cyberspace), sehingga tidak dapat dipastikan yurisdiksi negara mana yang berlaku terhadapnya.

2. Perbuatan tersebut dilakukan dengan menggunakan peralatan apa pun yang terhubung dengan internet.

3. Perbuatan tersebut mengakibatkan kerugian materiil maupun immateriil (waktu, nilai, jasa, uang, barang, harga diri, martabat, kerahasiaan informasi) yang cenderung lebih besar dibandingkan dengan kejahatan kovensional.

4. Pelakunya adalah orang yang menguasai penggunaan internet beserta aplikasinya.

5. Perbuat tersebut sering dilakukan secara transnasional/melintasi batas negara. ${ }^{10}$

Taylor $^{11}$ selanjutnya mengungkapkan empat kategori kejahatan komputer yakni sebagai berikut:

a. The computer as a target. The attack seeks to deny the legitimate users or owners of the system access to their data or computers. A Denial-of-Service (a.k.a.DOS or DDOS) attack or a virus that renders the computer inoperable would be examples of this category.

b. The computer as an instrument of the crime. The computer is used to gain some other criminal objective. For example, a thief may use a computer to steal personal information.

c. The computer as incidental to a crime. The computer is not the primary instrument of the crime; it simply facilitates it. Money laundering and the trading of child pornography would be examples of this category. d. Crimes associated with the prevalence of computers. This includes crimes against the computer industry, such as intellectual property theft and software piracy.

a. Sebuah. Komputer sebagai target. serangannya berusaha untuk menolak pengguna yang sah atau pemilik akses sistem ke data atau komputer mereka. Serangan Denial-of-Service (a.k.a.DOS atau DDOS) atau virus yang membuat komputer tidak beroperasi bisa menjadi contoh kategori ini.

b. Komputer sebagai alat kejahatan. Komputer digunakan untuk mendapatkan beberapa tujuan kriminal lainnya. Misalnya, pencuri bisa menggunakan komputer untuk mencuri informasi pribadi.

c. Komputer sebagai sesuatu yang bersifat insidentil terhadap kejahatan. Komputer bukanlah instrumen utama kejahatan; komputer hanya memfasilitasi itu. Pencucian uang dan perdagangan pornografi anak akan menjadi contoh kategori ini.

d. Kejahatan terkait dengan prevalensi komputer. Ini termasuk kejahatan terhadap industri komputer, seperti pencurian kekayaan intelektual dan pembajakan perangkat lunak (translasi oleh peneliti).

Perjudian online sebagai kejahatan di dunia maya karena kejahatan ini merupakan perbuatan melawan hukum yang dilakukan dengan pemanfaatan teknologi, menimbulkan kerugian, dan dapat dilakukan dengan melintasi batas negara. Sebagai kejahatan di dunia maya, maka isu yurisdiksi menjadi penting ketika suatu negara ingin melakukan penegakan hukum. Mengenai hal ini, H. Marshall Jarrett, Michael W. Bailie mengatakan "In the context of computer crime, the inexorable connection between the Internet and interstate commerce may sometimes be sufficient to satisfy the jurisdictional element of the statute at issue." 2 (Dalam konteks kejahatan komputer, hubungan yang tak terhindarkan antara Internet dan perdagangan antar negara terkadang cukup memadai untuk memenuhi elemen yurisdiksi undang-undang yang dipermasalahkan).

Pemikiran-pemikiran tradisional atas yurisdiksi didasari pada geografis dan kontak fisik yang dimiliki terdakwa dengan forum (baik secara langsung atau dengan jalan mengirimkan produk). Tetapi internet memungkinkan adanya peluang 
untuk "kontak virtual". Mengingat sifat kontak di internet, kontak seorang terdakwa dengan forum meungkin seluruhnya bersifat online, dan kontak fisiknya dengan forum mungkin tidak ada. Maka yurisdiksi diri atas seorang pengguna internet yang hanya memiliki kontak online dengan forum akan didasarkan pada sifat kontak tersebut. ${ }^{13}$

Darrel Menthe menyatakan bahwa yurisdiksi di cyber space membutuhkan prinsipprinsip yang jelas yang berakar dari hukum internasional. Hanya melalui prinsip-prinsip yurisdiksi dalam hukum internasional ini, negaranegara dapat dihimbau untuk mengadopsi pemecahan yang sama terhadap pertanyaan mengenai yurisdiksi internet. ${ }^{14}$ Pendapat Menthe ini dapat ditafsirkan bahwa dengan diakuinya prinsip-prinsip yurisdiksi yang berlaku dalam hukum internasional dalam kegiatan cyber space oleh setiap negara, maka akan mudah bagi negaranegara untuk mengadakan kerjasama dalam rangka harmonisasi ketentuan-ketentuan pidana untuk menanggulangi cyber crime. Pada hakikatnya untuk menentukan yurisdiksi manakah yang dapat diterapkan dalam kegiatan cyberspace, termasuk di dalamnya cyber crime, tidak perlu dicari yurisdiksi tertentu yang lain dari pada yang lain (yurisdiksi dengan karakteristik khusus), karena sebenarnya prinsip-prinsip dalam hukum internasional sudah memadai untuk dipergunakan. ${ }^{15}$ Dalam substansi hukum di Amerika terdapat beberapa teori yang berkaitan dengan yurisdiksi di cyber space yakni:

a. The theory of the uploader and the downloader(teori tentang mengunggah dan mengunduh). Uploader (pengunggah) adalah pihak yang memasukkan informasi elektronik ke dalam cyber space sedangkan downloader(pengunduh) adalah pihak yang mengakses informasi. Pada umumnya, yurisdiksi mengenai perbuatan-perbuatan perdata dan tindak pidana tidak ada kesulitan. Suatu negara dapat melarang dalam wilayahnya kegiatan uploading dan downloading yang diperkirakan dapat bertentangan dengan kepentingan negaranya. Misalnya, suatu negara dapat melarang setiap orang untuk uploading kegiatan perjudian dalam wilayah negaranya dan melarang setiap orang dalam wilayahnya untuk downloading kegiatan perjudian.

$b$. The theory of the law of the server(teori hukum pusat penyedia). Pendekatan lain yang dapat digunakan adalah memperlakukan server dimana webpages secara fisik berlokasi, yaitu dimana mereka dicatat sebagai data elektronik. Menurut teori ini sebuah webpages yang berlokasi di server pada Standford University tunduk pada hukum California. Namun teori ini akan sulit dipergunakan apabila uploader berada dalam yurisdiksi asing.

c. The theory of International Space(teori ruang internasional). Menurut teori ini, cyber space adalah lingkungan hukum yang terpisah dengan hukum konvensional dimana setiap negara memiliki kedaulatan yang sama. Dalam kaitan dengan teori ini Menthe mengusulkan agar cyber space menjadi fourth space. Yang menjadi dasar analogi tidak terletak pada kesatuan fisik, melainkan pada sifat internasional yakni sovereignless quality(kualitas kedaulatan). Semua kegiatan dalam cyber space dianalogikan dengan kegiatan ruang angkasa. Semua kegiatan ini diatur secara bersama-sama. ${ }^{16}$

Barda NawawiAriefmenuliskan mengenai empat model yang saling bersaing dengan merujuk pemikiran dariDavid R. Jhonson dan Davis G. Post, yaitu:

a. Pelaksanaan kontrol yang dilakukan oleh badan-badan pengadilan yang saat ini ada (the existing judicial forums).

b. Penguasa nasional melakukan kesepakatan internasional mengenai the governance of cyber space.

c. Pembentukan suatu organisasi internasional baru (a New International Organization) yang secara khusus menangani masalah-masalah di dunia internet.

d. Pemerintah atau pengaturan sendiri (self governance) oleh para pengguna internet. ${ }^{17}$

Johnson dan Post mendukung model pengaturan sendiri (selfgovernance) dibandingkan dengan model-model lainnya dengan alasan bahwa penerapan prinsip-prinsip tradisional dari Due Process and Personal Jurisdiction (proses dan yurisdiksi pribadi) tidak sesuai dan akan mengacaukan apabila diterapkan di dunia cyber space. Cyber space menurut mereka harus diperlakukan secara terpisah dari dunia nyata dengan menerapkan hukum yang berbeda untuk cyber space (cyber space should be treated as a separate space from the real world by applying distinct law to cyber space). ${ }^{18}$ 
Pandangan Johnson dan Post ini ternyata banyak mendapat kritikan dari para pakar hukum seperti Lawrence Lessig, Christoper Doran, Masaki Hamano termasuk juga Barda Nawawi Arief. Barda Nawawi Arief sependapat dengan apa yang disampaikan oleh Masaki Hamano bahwa sistem hukum dan yurisdiksi nasional atau teritorial memang memiliki keterbatasan, namun tidak berarti di ruang cyber dibiarkan bebas tanpa hukum. Cyber space juga merupakan bagian atau perluasan dari lingkungan hidup (life environment) yang perlu dipelihara dan dijaga kualitasnya. Jadi merupakan kepentingan hukum yang harus dilindungi. ${ }^{19}$ Asas teritorialitas didasarkan atas kedaulatan suatu negara atas wilayahnya sendiri. Asas tersebut menentukan bahwa hukum pidana berlaku bagi setiap orang yang melakukan tindak pidana di wilayah bersangkutan. Penegakan hukum yang dilakukan oleh negara di willayahnya merupakan kewajiban dalam memelihara ketertiban hukum. ${ }^{20}$

Dalam ketentuan hukum di Indonesia, yurisdiksi terhadap kejahatan di dunia maya dilakukan berdasarkan asas territorial atau kewilayahan. Hal itu dapat dilihat dari pengaturan dalam Pasal 2 Undang-undang Nomor 11 Tahun 2008 tentang Informasi dan Transaksi Elektronik. Ketentuan dalam Pasal 2 menyatakan sebagai berikut:

Undang-Undang ini berlaku untuk setiap Orang yang melakukan perbuatan hukum sebagaimana diatur dalam Undang-Undang ini, baik yang berada di wilayah hukum Indonesia maupun di luar wilayah hukum Indonesia, yang memiliki akibat hukum di wilayah hukum Indonesia dan/ atau di luar wilayah hukum Indonesia dan merugikan kepentingan Indonesia.

Yurisdiksi sebagaimama yang diatur dalam Pasal 2 Undang-undang Nomor 11 Tahun 2008 tentang Informasi dan Transaksi Elektronik menjangkau wilayah hukum yang sangat luas. Dalam hal ini perlu diperhatikan pula prinsip internasional dimana penegakan hukum baru dapat dilakukan apabila masing-masing negara menetapkan suatu perbuatan sebagai tindak pidana. Artinya, penegak hukum di Indonesia baru dapat melakukan kerjasama internasional dalam penegakan hukum dengan negara lain apabila Indonesia dan negara yang diminta tersebut samasama menetapkan perjudian online sebagai tindak pidana.
Indonesia bukan satu-satunya negara yang menetapkan perjudian online sebagai tindak pidana, namun tidak semua negara meletakkan perjudian online sebagai tindak pidana dalam kebijakn formulasi di negara bersangkutan. Negara-negara dalam kelompok tersebut justru melegalkan segala bentuk perjudian dengan aturan-aturan hukum yang telah ditegaskan. Convention on Cybercrime, Budapest, 23.XI.2001 sebagai perjanjian internasional pertama dalam menghadapi kejahatan di dunia maya yang ditandatangani di Budapest tanggal 23 November 2001 tidak mengatur perjudian online sebagai kejahatan di dunia maya. Bab II Convention on Cybercrime mengatur mengenai pendekatan-pendekatan yang harus diambil pada tingkat nasional pada hukum pidana materiil. Perjanjian internasional ini menguraikan perbuatanperbuatan yang termasuk cybercrime menjadi empat kategori yakni:

1) Offences against the confidentiality, integrity and availability of computer data and systems (Pelanggaran terhadap kerahasiaan, integritas dan ketersediaan data dan sistem komputer). Tindakan ini meliputi:

a. Illegal access/akses illegal.

b. Illegal interception/penyadapan ilegal

c. Data interference/gangguan data

d. System interference/gangguan sistem

e. Misuse of devices/ penyalahgunaan perangkat

2) Computer-related offences atau pelanggaran terkait komputer terdiri dari:

a. Computer-related forgery/ pemalsuan terkait komputer

b. Computer-related fraud/penipuan terkait komputer

3) Content-related offences atau pelanggaran yang terkait dengan konten Offences related to child pornography/perbuatan yang terkait dengan pornografi anak.

4) Offences related to infringements of copyright and related right/ pelanggaran terkait pelanggaran hak cipta dan hak terkait

Convention on Cybercrime juga mengantur mengenai ketentuan yurisdiksi dalam kejahatan di dunia maya. Ketentuan tersebut diatur dalam Pasal 22 Convention on Cybercrime yang menyatakan sebagai berikut: 
1. Each Party shall adopt such legislative and other measures as may be necessary to establish jurisdiction over any offence established in accordance with Articles 2 through 11 of this Convention, when the offence is committed:

a. in its territory; or

b. on board a ship flying the flag of that Party; or

c. on board an aircraft registered under the laws of that Party; or

d. by one of its nationals, if the offence is punishable under criminal law where it was committed or if the offence is committed outside the territorial jurisdiction of any State.

2. Each Party may reserve the right not to apply or to apply only in specific cases or conditions the jurisdiction rules laid down in paragraphs 1.b through 1.d of this article or any part thereof.

3. Each Party shall adopt such measures as may be necessary to establish jurisdiction over the offences referred to in Article 24, paragraph 1, of this Convention, in cases where an alleged offender is present in its territory and it does not extradite him or her to another Party, solely on the basis of his or her nationality, after a request for extradition.

4. This Convention does not exclude any criminal jurisdiction exercised by a Party in accordance with its domestic law.

5. When more than one Party claims jurisdiction over an alleged offence established in accordance with this Convention, the Parties involved shall, where appropriate, consult with a view to determining the most appropriate jurisdiction for prosecution.

1. Setiap Negara Pihak harus mengambil tindakan legislatif dan lainnya yang mungkin diperlukan untuk menetapkan yurisdiksi atas setiap pelanggaran yang ditetapkan sesuai dengan Pasal 2 sampai 11 Konvensi ini, bila pelanggaran tersebut dilakukan:

a. di wilayahnya; atau

b. di atas kapal yang mengibarkan bendera Negara Pihak itu; atau

c. di atas pesawat yang terdaftar berdasarkan undang-undang Negara Pihak tersebut; atau

d. oleh salah seorang warganya, jika pelanggaran tersebut dapat dihukum berdasarkan hukum pidana di mana undang-undang tersebut dilakukan atau jika pelanggaran tersebut dilakukan di luar wilayah yurisdiksi suatu Negara Bagian.

2. Setiap Negara Pihak berhak untuk tidak mengajukan permohonan atau hanya mengajukan permohonan dalam kasus atau ketentuan khusus yang diatur dalam ayat 1.b melalui 1.d Pasal ini atau bagiannya.

3. Setiap Negara Pihak harus menerapkan tindakan-tindakan yang mungkin diperlukan untuk menetapkan yurisdiksi atas pelanggaran sebagaimana dimaksud dalam Pasal 24 ayat 1 Konvensi ini, dalam kasus dimana pelaku yang diduga hadir di wilayahnya dan tidak mengekstradisi dia ke Negara Pihak lain, sematamata atas dasar kewarganegaraannya, setelah permintaan ekstradisi.

4. Konvensi ini tidak mengecualikan yurisdiksi pidana yang dilakukan oleh suatu Negara Pihak sesuai dengan hukum nasionalnya.

5. Bila lebih dari satu Negara Pihak mengklaim yurisdiksi atas dugaan pelanggaran yang ditetapkan sesuai dengan Konvensi ini, Pihak-pihak yang terlibat harus, bila perlu, berkonsultasi dengan maksud untuk menentukan yurisdiksi yang paling sesuai untuk penuntutan.

Pada dasarnya Indonesia dapat meminta kerjasama internasional dalam penegakan hukum terhadap perjudian online yang terkait dengan yurisdiksi negara lain, namun patut diingat kembali bahwa kerjasama dapat dilakukan sepanjang negara-negara tersebut juga menyatakan perjudian online sebagai perbuatan ilegal. Negara-negara yang melegalkan perjudian seperti misalnya Malaysia, Singapura, Yunani, Italia, Hongkong, tentunya tidak dapat bekerjasama dengan Indonesia dalam menanggulangi perjudian online, kecuali apabila perbuatan tersebut terkait dengan pencucian uang atau kegiatan pendanaan terorisme.

\section{Kebijakan Hukum Pidana terhadap Perjudian Online}

Politik hukum merupakan kebijakan yang dilakukan oleh negara melalui penetapan peraturan-peraturan yang dikehendaki dan juga diprediksi akan digunakan odan sesuai dengan masyarakat. Kebijakan tersebut dilakukan melalui badan-badan negara. ${ }^{21}$ Politik hukum pidana atau yang dapat juga disebut dengan kebijakan hukum pidana mengarahkan hukum pidana sebagai sarana 
untuk menanggulangi kejahatan. R.E. Dzhansarayeva, L. Bissengali,A.A. Bazilova, M.E. Akbolatova dan M.K. Bissenovamerumuskan bahwa criminal policy harus diartikan sebagai:

1) State policy (doctrine) of anticriminal fight expressed in associated directives (laws, Decrees of President, governmental regulations);

2) Specific type of social activity aimed at active countermeasures to criminality and other offences of law;

3) Scientific theory and synthesis of relevant political, sociological and legal knowledge. Therefore, in the determination of its matter the criminal policy relies on the integrative characteristics of state social policy, provisions of management theory and sciences of criminal law cycle and also the achievements of sociology and politology. ${ }^{22}$

1) Kebijakan negara (doktrin) pertarungan antikriminal yang diungkapkan dalam arahan terkait (undang-undang, keputusan Presiden, peraturan pemerintah);

2) Jenis aktivitas sosial tertentu yang ditujukan untuk tindakan pencegahan terhadap kriminalitas dan pelanggaran hukum lainnya;

3) Teori ilmiah dan sintesis pengetahuan politik, sosiologis dan hukum yang relevan. Oleh karena itu, dalam penentuan masalahnya kebijakan pidana bergantung pada karakteristik integratif dari kebijakan sosial negara, ketentuan teori manajemen dan ilmu siklus hukum pidana dan juga prestasi sosiologi dan politik.

Dalam melaksanakan pembangunan hukum, maka kebijakan hukum pidana harus dilakukan dalam beberapa tahapan. Dey Ravena dan Kristian menguraikan tahapan dalam kebijakan hukum pidana sebagai berikut:

1) Tahap formulasi. Kebijakan ini disebut juga dengan kebijakan legislatif(legislative policy) atau kebijakan formulasi. Kebijakan legislatif adalah kebijakan dalam perancangan undang-undang. Perancangan undang-undangan dilakukan melalui perencanaan yang rasional, sehingga undangundang yang dihasilkan nantinya benar-benar mencapai tujuan dalam menjawab permasalahan. Kebijakan formulasi pada pokoknya terdiri dari beberapa hal yakni:

a. Perumusan tindak pidana (criminal act). b. Perumusan pertanggungjawaban pidana (criminal responsibility atau criminal leability).

c. Perumusan sanksi baik berupa pidana maupun berupan tindakan tata tertib.

2) Tahap aplikasi. Tahapan aplikasi ini disebut juga dengan kebijakan yudikatif atau kebijakan yudisial (yudicial policy). Tahapan ini tidak dapat dipisahkan dari sistem peradilan pidana. Tahap aplikasi adalah tahap penegakan hukum terhadap tindak pidana oleh aparat penegak hukum.

3) Tahap eksekusi. Tahap ini disebut juga dengan kebijakan eksekuttif atau kebijakan administrative atau executive policy. Tahap eksekusi dilakukan oleh aparat pelaksana pidana.

4) Tahap evaluasi. Tahapan ini meerupakan tahapan penilaian atas pelaksanaan dan penegakan hukum dari masing-masing tahap sebelumnya. Tahap evaluasi dapat dilakukan oleh masyarakat dan kelompok masyarakat, misalnya dalam bentuk pengajuan gugatan uji materiil ke Mahkamah Konstitusi. $^{23}$

Kebijakan hukum pidana di masingmasing negara dilakukan sesuai dengan budaya hukum masyarakat di tempat dimana hukum itu dibuat. Terkait dengan perjudian online, ada negara yang melegalkan perjudian online, ada pula negara yang melarangnya. Negara-negara di Uni Eropa memiliki pengaturan tersendiri mengenai perjudian online, bahkan perjudian online dipandang sebagai salah satu varian bisnis. Mengenai hal tersebut,European Commission menyatakan sebagai berikut:

There is no sector-specific EU legislation in the field of gambling services. EU countries are autonomous in the way they organise their gambling services, as long as they comply with the fundamental freedoms established under the Treaty on the Functioning of the European Union (TFEU), as interpreted by the Court of Justice of the EU. The freedom to provide services or to open a business in another EU country is particularly relevant here.

Most EU countries allow at least some games of chance to be offered on the internet. Some countries allow all games, while others only allow certain types such as betting, poker or casino games. In some European jurisdictions, monopolistic regimes offering online gambling services have been established. 
These are run by a state-controlled public operator or by a private operator on the basis of an exclusive right. However, a growing number of EU countries have established licensing systems that allow more than 1 operator to offer services on the market. Under EU law, no particular system is favoured over the others. ${ }^{24}$

Tidak ada undang-undang UE khusus sektor di bidang layanan perjudian. Negara-negara UE otonom dalam cara mereka mengatur layanan perjudian mereka, selama mereka mematuhi kebebasan mendasar yang ditetapkan berdasarkan Perjanjian tentang Fungsi Uni Eropa (TFEU), sebagaimana ditafsirkan oleh Pengadilan Kehakiman Uni Eropa. Kebebasan untuk memberikan layanan atau untuk membuka bisnis di negara UE lainnya sangat relevan di sini.

Sebagian besar negara UE mengizinkan setidaknya beberapa game kesempatan untuk ditawarkan di internet. Beberapa negara mengizinkan semua permainan, sementara yang lain hanya mengizinkan jenis tertentu seperti taruhan, permainan poker atau kasino. Di beberapa yurisdiksi Eropa, rezim monopolistik yang menawarkan layanan judi online telah dibentuk. Ini dijalankan oleh operator publik yang dikendalikan negara atau oleh operator swasta berdasarkan hak eksklusif. Namun, semakin banyak negara Uni Eropa telah membentuk sistem perizinan yang memungkinkan lebih dari 1 operator menawarkan layanan di pasar. Di bawah hukum Uni Eropa, tidak ada sistem tertentu yang lebih disukai daripada yang lain

Kebijakan hukum pidana terhadap perjudian online di beberapa negara dapat dikatakan berada di daerah abu-abu. Terkait hal tersebut, Ed Grabianowski mengatakan sebagai berikut:

Gambling online falls into a legal grey area. While it is technically illegal in most of the United States, the prosecution and conviction of individual players is very difficult because they're gambling from home. It is also illegal for a gambling Web site to operate within the United States, which is why the offices and servers of most online casinos are located in other countries. There are about 70 countries that allow online gambling sites to set up shop, including Australia, New Zealand,
South Korea, Denmark, Finland, France, Germany, and some provinces of Canada. ${ }^{25}$

Perjudian online jatuh ke area abu-abu yang legal. Meskipun secara teknis ilegal di sebagian besar Amerika Serikat, penuntutan dan hukuman pemain individu sangat sulit karena mereka berjudi dari rumah. Juga ilegal bagi situs Web judi untuk beroperasi di Amerika Serikat, itulah sebabnya kantor dan server sebagian besar kasino online berlokasi di negara lain. Ada sekitar 70 negara yang memungkinkan situs perjudian online untuk mendirikan toko, termasuk Australia, Selandia Baru, Korea Selatan, Denmark, Finlandia, Prancis, Jerman, dan beberapa provinsi di Kanada. Tobias Roberts melaporkan, di Amerika Serikat, salah satu bentuk pendapatan utama bagi puluhan komunitas asli berasal dari kasino yang dioperasikan secara mandiri dan independen oleh otoritas reservasi. Dalam banyak kasus, keuntungan yang dihasilkan dari kasino-kasino ini adalah kontributor utama bagi orang-orang yang telah lama berada di antara yang termiskin dan paling terpinggirkan di negara ini. Selain itu, pendapatan dari kasino-kasino ini sering diinvestasikan kembali ke dalam bentuk penciptaan lapangan kerja lainnya. Lebih dari tiga perempat keuntungan dari kasino yang dijalankan oleh Bangsa Cherokee baru-baru ini diinvestasikan kembali ke dalam dana pertumbuhan pekerjaan yang membantu anggota suku Cherokee lainnya menemukan peluang kerja yang bermakna dan stabil.Satu studi menemukan bahwa pada tahuntahun awal kebanyakan game online yang tidak diatur, lebih dari $\$ 0,30$ dari setiap dolar diambil dari kasino komersial, termasuk kasino yang dikelola oleh India, oleh industri perjudian online. Namun, terlepas dari potensi kerugian dalam pendapatan penting yang dapat disebabkan oleh penyebaran dan pertumbuhan perjudian online, beberapa suku asli di Amerika Serikat yang menjalankan kasino ingin memperluas ke industri perjudian online. Jika berhasil diterapkan, ini akan membantu suku-suku meningkatkan pendapatan melalui pemasaran ke audiens dari seluruh dunia bersama dengan pelanggan reguler dari wilayah mereka. ${ }^{26}$

Kebijakan formulasi perjudian online diatur dalam peraturan perundang-undangan di Indonesia. Pasal 27 ayat (2) Undang-undang Nomor 11 Tahun 2008 tentang Informasi dan Transaksi Elektronik yang menyatakan "Setiap 
Orang dengan sengaja dan tanpa hak mendistribusikan dan/atau mentransmisikan dan/ atau membuat dapat diaksesnya Informasi Elektronik dan/atau Dokumen Elektronik yang memiliki muatan perjudian.' Frasa perjudian sendiri dapat dijelaskan dengan intepretasi sistematis terhadap KUHP yakni dalam Pasal 303 KUHP yang menyatakan sebagai berikut:

(1) Diancam dengan pidana penjara paling lama sepuluh tahun atau pidana dendapaling banyak dua puluh lima juta rupiah, barang siapa tanpa mendapatizin:

1. dengan sengaja menawarkan atau memberikan kesempatan untuk permainan judi danmenjadikannya sebagai pencarian, atau dengan sengaja turut serta dalam suatuperusahaan untuk itu;

2. dengan sengaja menawarkan atau memberi kesempatan kepada khalayak umum untukbermain judi atau dengan sengaja turut serta dalam perusahaan untuk itu, dengantidak peduli apakah untuk menggunakan kesempatan adanya sesuatu syarat ataudipenuhinya sesuatu tata-cara;

3. menjadikan turut serta pada permainan judi sebagai pencarian.

(2) Kalau yang bersalah melakukan kejahatan tersebut dalam menjalankanpencariannya, maka dapat dicabut haknya untuk menjalankan pencarian itu.

(3) Yang disebut permainan judi adalah tiap-tiap permainan, di mana pada umumnyakemungkinan mendapat untung bergantung pada peruntungan belaka, juga karenapemainnya lebih terlatih atau lebih mahir. Di situ termasuk segala pertaruhantentang keputusan perlombaan atau permainanlain-lainnya yang tidak diadakanantara mereka yang turut berlomba atau bermain, demikian juga segala pertaruhanlainnya.

Penerapan perjudian sebagai suatu tindak pidana dapat hilang sifat perbuatan melawan hukum jika perjudian itu mendapat izin dari pihak yang berwenang sehingga perjudian itu menjadi sah atau legal. ${ }^{27}$ Hilangnya sifat melawan hukum tersebut dapat dilihat dari frasa "barang siapa tanpa mendapat izin", oleh sebab itu setiap orang yang mendapat izin maka tidak dapat dipidana.

Penegakan hukum terhadap pelaku perjudian online dilakukan melalui proses peradilan pidana. Pembuktian adalah tahapan yang sangat penting dalam proses peradilan pidana.
Pembuktian dalam pengertian hukum acara pidana adalah ketentuan yang membatasi sidang pengadilan dalam usaha mencari dan mempertahankan kebenaran, baik oleh hakim, penuntut umum, terdakwa, maupun penasehat hukum, dari semua tingkatan itu, maka ketentuan dan tata cara serta penilaian alat bukti ditentukan oleh undang-undang. ${ }^{28} \mathrm{Di}$ dalam teori dikenal dua sistem pembuktian sebagaimana yang ditulis oleh Alfitra yaitu: ${ }^{29}$

a. Sistem pembuktian positif. Sistem pembuktian positif (positief wetelijk) adalah sistem pembuktian yang menyandarkan diri pada alat bukti saja, yakni alat bukti yang telah ditentukan oleh undang-undang. Seorang terdawa bisa dinyatakan bersalah melakukan tindak pidana hanya didasarkan pada alat bukti yang sah. Alat bukti yang ditetapkan oleh undang-undang adalah penting. Keyakinan hakim sama sekali diabaikan.

b. Sistem pembuktian negatif. Sistem pembuktian negative (negatief wettelijk) sangat mirip dengan sistem pembuktian conviction in raisone. Hakim di dalam mengambil keputusan tentang salah atau tidaknya seorang terdakwa terikat oleh alat bukti yang ditentukan oleh undang-undang dan keyakinan (nurani) hakim sendiri. Jadi, di dalam sistem negatif ada dua hal yang merupakan syarat untuk membuktikan kesalahan terdakwa, yakni

1) Wettelijk: adanya alat bukti yang sah yang telah ditetapkan oleh undang-undang.

2) Negatief: adanya keyakinan (nurani) dari hakim, yakni berdasarkan bukti-bukti tersebut hakim meyakini kesalahan tedakwa.

Pembuktian dilakukan dengan serangkaiajn alat bukti. Menurut Pasal 44 Undangundang Nomor 11 Tahun 2008 tentang Informasi dan Transaksi Elektronikyang tergolong alat bukti adalah sebagai berikut:

Alat bukti penyidikan, penuntutan dan pemeriksaan di sidang pengadilan menurut ketentuan Undang-Undang ini adalah sebagai berikut:

a. alat bukti sebagaimana dimaksud dalam ketentuan Perundang-undangan; dan

b. alat bukti lain berupa Informasi Elektronik dan/ atau Dokumen Elektronik sebagaimana dimaksud dalam Pasal 1 angka 1 dan angka 4 serta Pasal 5 ayat (1), ayat (2), dan ayat (3). 
Alat bukti sebagaimana dimaksud dalam ketentuan Perundang-undangandalam Pasal 44 a merujuk pada ketentuan dalam Pasal 184 ayat (1) KUHAP yang menyatakan sebagai berikut:

Alat bukti yang sah ialah:

a. keterangan saksi;

b. keterangan ahli;

c. surat;

d. petunjuk;

e. keterangan terdakwa.

Pasal 185 KUHAP mengatur mengenai ketentuan keterangan saksi sebagai alat bukti. Adapun dalam Pasal 185 KUHAP dinyatakan sebagai berikut:

(1) Keterangan saksi sebagai alat bukti ialah apa yang saksi nyatakan di sidang pengadilan.

(2) Keterangan seorang saksi saja tidak cukup untuk membuktikan bahwa terdakwa bersalah terhadap perbuatan yang didakwakan kepadanya.

(3) Ketentuan sebagaimana dimaksud dalam ayat (2) tidak berlaku apabila disertai dengan suatu alat bukti yang sah lainnya.

(4) Keterangan beberapa saksi yang berdiri sendiri-sendiri tentang suatu kejadian atau keadaan dapat digunakan sebagai suatu alat bukti yang sah apabila keterangan saksi itu ada hubungannya satu dengan yang lain sedemikian rupa, sehingga dapat membenarkan adanya suatu kejadian atau keadaan tertentu.

(5) Baik pendapat maupun rekaan, yang diperoleh dari hasil pemikiran saja, bukan merupakan keterangan ahli.

(6) Dalam menilai kebenaran keterangan seorang saksi, hakim harus dengan sungguh-sungguh memperhatikan:

a. persesuaian antara keterangan saksi satu dengan yang lain;

b. persesuaian antara keterangan saksi dengan alat bukti lain;

c. alasan yang mungkin dipergunakan oleh saksi untuk memberi keterangan yang tertentu;

d. cara hidup dan kesusilaan saksi serta segala sesuatu yang pada umumnya dapat mempengaruhi dapat tidaknya keterangan itu dipercaya;

(7) Keterangan dari saksi yang tidak disumpah meskipun sesuai satu dengan yang lain, tidak merupakan alat bukti, namun apabila keterangan itu sesuai dengan keterangan dari saksi yang disumpah dapat dipergunakan sebagai tambahan alat bukti sah yang lain.

Pasal 1 angka 28 KUHAP menyatakan keterangan ahli adalah keterangan yang diberikan oleh seorang yang memiliki keahlian khusus tentang hal yang diperlukan untuk membuat terang suatu perkara pidana guna kepentingan pemeriksaan.Pasal 186 KUHAP selanjutnya menyatakan sebagai berikut'Keterangan ahli ialah apa yang seorang ahli nyatakan di sidang pengadilan." Peranan ahli dalam proses pembuktian dapat dilihat dari sejumlah ketentuan pasal berikut ini:

Pasal 132 ayat (1) KUHAP

Dalam hal diterima pengaduan bahwa sesuatu surat atau tulisan palsu atau dipalsukan atau diduga palsu oleh penyidik, maka untuk kepentingan penyidikan, oleh penyidik dapat dimintakan keterangan mengenai hal itu dari orang ahli;

Pasal 133 ayat (1) KUHAP

Dalam hal penyidik untuk kepentingan peradilan menangani seorang korban baik luka, keracunan ataupun mati yang diduga karena peristiwa yang merupakan tindak pidana, ia berwenang mengajukan permintaan keterangan ahli kepada ahli kedokteran kehakiman atau dokter dan atau ahli lainnya

Pasal 179 ayat (1) KUHAP

Setiap orang yang diminta pendapatnya sebagai ahli kedokteran kehakiman atau dokter atau ahli lainnya wajib memberikan keterangan ahli demi keadilan

Pasal 187 KUHAP mengatur mengenai alat bukti surat. Surat sebagaimana tersebut pada Pasal 184 ayat (1) huruf c, dibuat atas sumpah jabatan atau dikuatkan dengan sumpah, adalah:

a. berita acara dan surat lain dalam bentuk resmi yang dibuat oleh pejabat umum yang berwenang atau yang dibuat di hadapannya, yang memuat keterangan tentang kejadian atau keadaan yang didengar, dilihat atau yang dialaminya sendiri, disertai dengan alasan yang jelas dan tegas tentang keterangannya itu

b. surat yang dibuat menurut ketentuan peraturan perundang-undangan atau surat yang dibuat oleh pejabat mengenai hal yang termasuk dalam tata laksana yang menjadi tanggung jawabnya dan yang diperuntukkan bagi pembuktian sesuatu hal atau sesuatu keadaan; 
c. surat keterangan dari seorang ahli yang memuat pendapat berdasarkan keahliannya mengenai sesuatu hal atau sesuatu keadaan yang diminta secara resmi dari padanya;

d. surat lain yang hanya dapat berlaku jika ada hubungannya dengan isi dari alat pembuktian yang lain.

Pasal 188 menguraikan mengenai alat bukti petunjuk, yakni sebagai berikut:

(1)Petunjuk adalah perbuatan, kejadian atau keadaan, yang karena persesuaiannya, baik antara yang satu dengan yang lain, maupun dengan tindak pidana itu sendiri, menandakan bahwa telah terjadi suatu tindak pidana dan siapa pelakunya;

(2)Petunjuk sebagaimana dimaksud dalam ayat (1) hanya dapat diperoleh dari:

a. keterangan saksi;

b. surat;

c. keterangan terdakwa.

(3)Penilaian atas kekuatan pembuktian dari suatu petunjuk dalam setiap keadaan tertentu dilakukan oleh hakim dengan ariflagi bijaksana setelah ia mengadakan pemeriksaan dengan penuh kecermatan dan kesaksamaan berdasarkan hati nuraninya.

Pasal 189 KUHAP mengatur mengenai alat bukti keterangan terdakwa. Dalam ketentuan tersebut dinyatakan sebagai berikut:

(1)Keterangan terdakwa ialah apa yang terdakwa nyatakan di sidang tentang perbuatan yang ia lakukan atau yang ia ketahui sendiri atau alami sendiri.

(2)Keterangan terdakwa yang diberikan di luar sidang dapat digunakan untuk membantu menemukan bukti di sidang, asalkan keterangan itu didukung oleh suatu alat bukti yang sah sepanjang mengenai hal yang didakwakan kepadanya.

(3)Keterangan terdakwa hanya dapat digunakan terhadap dirinya sendiri.

(4)Keterangan terdakwa saja tidak cukup untuk membuktikan bahwa ia bersalah melakukan perbuatan yang didakwakan kepadanya, melainkan harus disertai dengan alat bukti yang lain.

Dalam pembuktian perjudian online, maka kelima alat bukti sebagaimana yang dimaksud dalam KUHAP digunakan untuk memeriksa perkara, dan tentunya ditambah dengan alat bukti lain berupa Informasi Elektronik dan/atau
Dokumen Elektronik. Menurut Pasal 1 angka 1 Undang-undang Nomor 19 Tahun 2016 dinyatakan Informasi Elektronik adalah satu atau sekumpulan data elektronik, termasuk tetapi tidak terbatas pada tulisan, suara, gambar, peta, rancangan, foto, electronic data interchange (EDI), surat elektronik (electronic mail), telegram, teleks, telecopy atau sejenisnya, huruf, tanda, angka, Kode Akses, simbol, atau perforasi yang telah diolah yang memiliki arti atau dapat dipahami oleh orang yang mampu memahaminya. Selanjutnya dalam Pasal 1 angka 4 dinyatakan Dokumen Elektronik adalah setiap Informasi Elektronik yang dibuat, diteruskan, dikirimkan, diterima, atau disimpan dalam bentuk analog, digital, elektromagnetik, optikal, atau sejenisnya, yang dapat dilihat, ditampilkan, dan/atau didengar melalui Komputer atau Sistem Elektronik, termasuk tetapi tidak terbatas pada tulisan, suara, gambar, peta, rancangan, foto atau sejenisnya, huruf, tanda, angka, Kode Akses, simbol atau perforasi yang memiliki makna atau arti atau dapat dipahami oleh orang yang mampu memahaminya. Menurut Pasal 5Undang-undang Nomor 11 Tahun 2008 tentang Informasi dan Transaksi Elektronik ditentukan:

(1)Informasi Elektronik dan/atau Dokumen Elektronik dan/atau hasil cetaknya merupakan alat bukti hukum yang sah.

(2)Informasi Elektronik dan/atau Dokumen Elektronik dan/atau hasil cetaknya sebagaimana dimaksud pada ayat (1) merupakan perluasan dari alat bukti yang sah sesuai dengan Hukum Acara yang berlaku di Indonesia.

(3)Informasi Elektronik dan/atau DokumenElektronik dinyatakan sah apabila menggunakan Sistem Elektronik sesuai dengan ketentuan yang diatur dalam Undang-Undang ini.

(4)Ketentuan mengenai Informasi Elektronik dan/ atau Dokumen Elektronik sebagaimana dimaksud pada ayat (1) tidak berlaku untuk:

a. surat yang menurut Undang-Undang harus dibuat dalam bentuk tertulis; dan

b. surat beserta dokumennya yang menurut Undang-Undang harus dibuat dalam bentuk akta notaril atau akta yang dibuat oleh pejabat pembuat akta.

Terkait dengan perkara perjudian online, Josua Sitompul mengatakan ada dua alat bukti yang dapat digunakan yakni: 
1. Bukti transfer dapat dijadikan alat bukti yang sah karena bukti transfer merupakan hasil cetak dari informasi atau dokumen elektronik;

2. E-mail dapat dijadikan alat bukti yang sah karena e-mail merupakan dokumen elektronik. ${ }^{30}$

Ketentuan mengenai sanksi bagi pelaku perjudian online diatur dalam Pasal 45 ayat (2) Undang-undang Nomor 19 Tahun 2016 tentang Perubahan Atas Undang-undang Nomor 11 Tahun 2008 tentang Informasi dan Transaksi Elektronik yang menyatakan"Setiap Orang yang dengan sengaja dan tanpa hak mendistribusikan dan/atau mentransmisikan dan/atau membuat dapat diaksesnya Informasi Elektronik dan/atau Dokumen Elektronik yang memiliki muatan perjudian sebagaimana dimaksud dalam Pasal 27 ayat (2) dipidana dengan pidana penjara paling lama 6 (enam) tahun dan/atau denda paling banyak Rp1.000.000.000,00 (satu miliar rupiah)."

Meskipun kebijakan formulasi terhadap perjudian online sudah secara tegas memidana pelaku, namun dalam pendekatan hukum pidana modern, kebijakan pencegahan tetap menjadi hal yang diutamakan. Baharuddin lopa menawarkan langkah-langkah preventif dalam pencegahan kejahatan yaitu antara lain:

1. Peningkatan kesejahteraan rakyat untuk mengurangi pengangguran, yang dengan sendirinya akan mengurangi kejahatan.

2. Memperbaiki sistem administrasi dan pengawasan untuk mencegah terjadinya penyimpangan-penyimpangan.

3. Peningkatan penyuluhan hukum untuk memeratakan kesadaran hukum rakyat.

4. Menambah personil kepolisian dan personil penegak hukum lainnya untuk lebih meningkatkan tindakan represif maupun preventif. ${ }^{31}$

Langkah preventif untuk mencegah perjudian online dilakukan dengan membatasi diri pada pergaulan yang mengarah pada perjudian, membangun sistem keamanan di dunia maya, dan meningkatkan patrol di dunia maya.

\section{Penutup}

Penerapan yurisdiksi dalam tindak pidana perjudian online diatur dalam Pasal 2 Undangundang Nomor 11 Tahun 2008 tentang Informasi dan Transaksi Elektronik yang menyatakan bahawa Undang-Undang ini berlaku untuk setiap Orang yang melakukan perbuatan hukum sebagaimana diatur dalam Undang-Undang ini, baik yang berada di wilayah hukum Indonesia maupun di luar wilayah hukum Indonesia, yang memiliki akibat hukum di wilayah hukum Indonesia dan/atau di luar wilayah hukum Indonesia dan merugikan kepentingan Indonesia. Perjudian online pada dasarnya adalah kejahatan lintas batas negara sehingga dalam hal ini menggunakan asas teritorialitas. Kerjasama internasional dalam penegakan hukum terhadap perjudian online dapat dilakukan sepanjang terdapat perjanjian internasional antar negara dan kedua negara tersebut sama-sama menetapkan perjudian online sebagai tindak pidana. Kebijakan hukum pidana terhadap perjudian online di Indonesia memformulasikan perjudian online sebagai tindak pidana. Kebijakan tersebut diformulasikan dalam Pasal 27 ayat (2) Undangundang Nomor 11 Tahun 2008 tentang Informasi dan Transaksi Elektronik yang menyatakan "Setiap Orang dengan sengaja dan tanpa hak mendistribusikan dan/atau mentransmisikan dan/ atau membuat dapat diaksesnya Informasi Elektronik dan/atau Dokumen Elektronik yang memiliki muatan perjudian."

\section{DAFTAR PUSTAKA}

Abdul Wahid dan M. Labib, 2005, Kejahaan Mayantara(cybercrime), Refika Aditama, Bandung.

Adami Chazawi dan Ardi Ferdian, 2011, Tindak Pidana Informasi dan Transaksi Elektronik; Penyerangan terhadap Kepentingan Hukum Pemanfaatan Teknologi Informasi dan Transaksi Elektronik, Bayumedia, Malang.

Alfitra, 2012, Hukum Pembuktian Dalam Beracara Pidana. Perdata dan Korupsi di Indonesia, Raih Asa Sukses, Depok.

Andi Hamzah, 2010. Asas-asas Hukum Pidana, Rineka Cipta, Jakarta, h. 66.

Baharuddin Lopa, 2001, Kejahatan Korupsi dan Penegakan Hukum, Rajawali Press, Jakarta.

Barda Nawawi Arief, 2006, Tindak Pidana Mayantara Perkembangan Kajian Cyber Crime di Indonesia, RajaGrafindo Persada, Jakarta. 
Dey Ravena dan Kristian, 2017, Kebijakan Kriminal (Criminal Policy), Kencana, Jakarta.

Dikdik M. Arief Mansur dan Elisatris Gultom, 2005, Cyber Law-Aspek Hukum Teknologi Informasi, Refika Aditama, Bandung.

H. Marshall Jarrett, Michael W. Bailie, Prosecuting Computer Crimes Computer Crime and Intellectual Property Section Criminal Division, Office of Legal Education Executive Office for United States Attorneys, Washington, DC.

Kartini Kartono, 2005, Patologi Sosial, jilid I, PT Raja Grafindo Persada, Jakarta.

Maskun, 2014, Kejahatan Cyber; Cyber Crime, Kencana Prenada Media Grup, Jakarta.

Muladi dan Diah Sulistyani R.S., 2016, Kompleksitas Perkembangan Tindak Pidana dan Kebijakan Kriminal, Alumni, Bandung.

Onno W Purbo, 2007, Kebangkitan Nasional Ke-2 Berbasis Teknologi Informasi, Computer Network Research Group, ITB, Bandung.

Otje Salman dan Anton F. Susanto, 2009, Teori Hukum Mengingat, Mengumpulkan dan Membuka Kembali, Refika Aditama, Bandung.

R.E. Dzhansarayeva, et.al., "Problems of Formation of the Concept of Criminal Policy of State in the Theory of Criminal Law", Middle-East Journal of Scientific Research 14 (4): 508-515, 2013

Syaiful Bakhri, 2015, Sistem Peradilan Pidana Indoensia dalam Perspektif Pembaruan, Teori dan Praktik Peradilan, Pustaka Pelajar, Yogyakarta.

Tien S. Saifullah, Yurisdiksi sebagai Upaya Penagakan Hukum dalam Kegiatan Cyberspace”, Cyber Law: Suatu Pengantar, Pusat Studi Cyber Law, UNPAD, Bandung.

Tuwo, C. P. C. 2016. "Penerapan Pasal 303 Kitab Undang-undang Hukum Pidana Tentang Perjudian", Lex Crimen, 5(1).

Widodo, 2009, Sistem Pemidanaan dalam Cyber Crime; Alternatif Ancaman
Oidana Kerja Sosial dan Pidana Pengawasan Bagi Pelaku Cyber Crime, Laksbang, Yogyakarta.

Detik.com, Polisi Ungkap Judi Bola Online, Total Transaksi Capai Rp 450 Mdalam 2 Tahun, https://news.detik.com/berita/d-2592674/ polisi-ungkap-judi-bola-online-totaltransaksi-capai-rp-450-m-dalam-2-tahun

Ed Grabianowski, The Legality of Online Gambling, https:// entertainment.howstuffworks.com/onlinegambling2.htm

European Commission, Online gambling in the $E U$, https://ec.europa.eu/growth/sectors/ gambling en

Internet World Stats, Internet Users in the World by Region-March 2019, https:// www.internetworldstats.com/stats.htm

Josua Sitompul, Cara PenyidikMenjerat Pelaku Perjudian Internet, https:// www.hukumonline.com/klinik/detail/ulasan/ cl4903/pembuktian-perjudian-melaluiinternet

Liputan 6, Empat Perempuan Jadi Bandar Judi Online Beromzet Miliaran Rupiah di Kepulauan Riau, https:// www.liputan6.com/regional/read/3504923/ empat-perempuan-jadi-bandar-judi-onlineberomzet-miliaran-rupiah-di-kepulauan-riau

TechAddiction, Online Gambling Statistics \& Facts, http://www.techaddiction.ca/onlinegambling-statistics.html.

Tobias Roberts, The Ripple Effect of the Online Gambling Industry, https:// www.huffpost.com/entry/the-ripple-effecto f - t h e - o n 1 i n e - g a m b li n g industry_b_5a3c0bbce4b0d86c803c7012 